\title{
FURTHER EVIDENCE ON THE LINK BETWEEN FIRM'S CONTROL MECHANISMS AND FIRM FINANCIAL PERFORMANCE: SULTANATE OF OMAN
}

\author{
Essia Ries Ahmed1,*, Tariq Tawfeeq Yousif Alabdullah², Muhammad Shabir Shaharudin ${ }^{3}$ Eskasari Putri4 \\ ${ }^{1}$ Collage of Economics, Management and Information Systems, University of Nizwa, Oman. \\ ${ }^{2}$ Accounting Department, College of Administration and Economics, University of Basrah, Iraq. \\ ${ }^{3}$ Faculty of Industrial Management, Universiti Malaysia Pahang, Malaysia. \\ ${ }^{4}$ Faculty of Economics and Business, Universitas Muhammadiyah Surakarta, Indonesia.
}

ABSTRACT - Based on the agency theory perspective and its corporate governance problem, the current study investigated how control mechanisms affect firm financial performance with a special concentrate on the role of the audit committee on the enhancement of firm financial performance. The empirical findings of this study based on the listed firms in the Sultanate of Oman revealed that the control mechanisms, including committee size and board independence, positively enhance financial performance represented by ROE and therefore this leads to encouraging firms to focus on such mechanisms. By contrast, audit size, board size and board independence are totally not motivated to engage with financial performance due to the insignificant link with ROA. On the other hand, a negative correlation has been found between a board meeting and financial performance represented by ROE. The practical evidence of the implications by the current study found that for improvement of firm financial performance; that even though if most of the GCC governments recently have focused on corporate social responsibility because largely voluntary nature of corporate social responsibility, they should focus of the control mechanisms that suggested by the current study to play a significant role for enhancing firm financial performance.
ARTICLE HISTORY

Received: 2-8-2020

Accepted: $13-10-2020$

\section{KEYWORDS}

Control Mechanisms,

Audit Committee,

Financial Performance, Corporate governance, Agency Theory

\section{INTRODUCTION}

Control mechanisms have helped to solve several problems related to regulations, laws, and declining performance and in addition to matters related to corporate governance risk management via pursuing to reach a positive impact of firms' performance (Alabdullah, Ahmed, \& Muneerali, 2019; Alabdullah, Ahmed, \& Nor, 2019). Therefore, control mechanisms have been used by the management to have a right level of effectiveness, efficiency, and transparency in their firms in order to enhance the firms' performance (Alabdullah, Laadjal, Ahmed, \& Al-Asadi, 2018). However, some listed firms are facing problems and lack in their financial performance because of many reasons such as manipulation and fraud in the financial reporting, and this leads to the weakness in the financial performance in the listed firms in the Sultanate of Oman and other Gulf Cooperation Council (GCC) countries.

As it concludes by trends of the previous studies in the literature review, it is evident that one of the primary purposes to strengthen reforms in Oman is going forward to improving firm financial performance (Ahmed et al., 2020). As in other emerging economies, the non-financial sector has been related to the general policy aims of obtaining a higher level of economic enhancement and higher performance of the firms and reducing poverty (Nagirikandalage, 2020). In developing markets, including Oman, the main concern is toward control mechanisms, including transparency practises (Aguilera, \& Haxhi, 2019). Hereher et al. (2020) mentioned that Oman is a distinguished country with a high geographical and economic position and there are three bodies of water overlooking the Sultanate of Oman: the Arabian Gulf, the Arabian Sea, and Bahr. It also has a coastal frontage of more than $3000 \mathrm{~km}$. The current study contributes to add knowledge to the literature review by filling the gap that could be considered as observation in the literature as regards financial performance in non-financial firms in the sultanate of Oman at the practical and theoretical level. In that, from a theoretical level, It adds knowledge to the current literature via adopting and testing its independent and dependent variables, where there has been a lack in the literature review in testing such variables. In addition, it helps management 
and policymakers to focus on some critical control mechanisms that should be applied by the management of the nonfinancial firms in Oman, and this reflects the empirical contribution perspective.

The rest sections of the paper are organised as follow: previous studies that represented section 2 as a literature review. While section 3 illustrates the method of the current study. In addition, section 4 explains the results. For section 5 and 6 : they provide both discussions and conclusions of the present study.

\section{LITERATURE REVIEW}

This study focused on what has been done recently in the literature review in the last three years regarding the control mechanisms and their impact on firm financial performance in GCC. Control mechanisms have several instruments that are useful for maximising for performance and firm value as well (Ahmed, Alabdullah, Thottoli, and Maryanti, 2020; Alabdullah, Nor, \& Ries, 2018).

Al-ahdal did a study, Alsamhi, Tabash, and Farhan, (2020) investigated the impact of control mechanisms on corporate performance in the listed firms for both those belong to Indian and also listed firms in the GCC. The findings reveal that board accountability and audit committee do not affect firm performance measured by Tobin's Q and ROE. Forcadell, Sanchez-Riofrio, Guerras-Martín, and Romero-Jordán, (2020) study the impact institutional environment business strategy and firm performance. The findings illustrate that there is a significant link between them. Another study tested the relationship between corporate governance and firm performance in Oman contest (Ahmed et al., 2020). The findings revealed a positive between the set of the independent variables represented by ownership, the board size, audit committee and gender and firm financial performance. Akira (2020) investigated the impact of mergers and acquisitions on the profitability, and the results show that there is no significant impact in return on assets as an indicator of the profitability. Also, recently, a study was done by Kushkowski, Shrader, Anderson, and White, (2020). They evaluate a set of control mechanisms via using bibliometric analysis for the articles that have been done by the researchers. The results illustrate that control mechanisms are far more interdisciplinary than previously thought. Naciti (2019) investigated the impact of board of directors' composition on firms' sustainability performance. The findings revealed that there is a negative link between independency and sustainability performance. Gao, Huang, and Yang, (2019) examined the relationship between ownership structure and firm performance and the findings show that there is a positive link between ownership structure and market responses. García-Sánchez, Hussain, and Martínez-Ferrero (2019) tested the ability of internal control to help firms reduce agency problems and the impact on both environmental and social performance. They found a strong relationship between CEO ability and internal control mechanisms in enhancing firm performance. Abdallah and Ismail (2017) explore the link of ownership and the levels of concentrated ownership in firm performance. The findings show that there is a positive link between their quality and firm performance. Pillai and Al-malkawi have done similar research. (2017) who tested the impact of internal control mechanisms on firm performance in the GCC countries. They found that audit type, the board size, and leverage have a positive impact on the performance of the firms listed in the GCC countries. Based on the above, it could be realised that control mechanisms have a significant role in monitoring the firms and enhancing firm performance. Thus, the current study developed these two hypotheses:

H1: A positive link between control mechanisms and firm performance (ROA).

$\mathrm{H} 2$ : A positive link between the audit committee and firm performance (ROA).

\section{Underpinning Theory}

Agency theory notion lies in separating the role between the agent and the principal to limit the behaviour of the agent (managers) for not maximising their wealth of the account of the wealthiest the principal (shareholders). Therefore, there is an eternal conflict between these two parties represented by the conflict of interests. Thus, control mechanisms of corporate governance came to be as a critical solution for solving problems that arise between them (Gibson, 2003).

Based on agency theory, that strongly suggests that there should be a positive link between board independence, board meeting, and firm performance (Rashid, 2018). Tobin's q is a proxy for firm value, as mentioned by (Lo \& Sheu, 2007). In the same line, Thomsen and Pedersen (2006) mentioned that Tobin's Q is proper to be as the measurement of stock market value. Our study excluded Tobin's $Q$ because this measurement is for firm value, and it is market-based value, while the aim of our study is accounting based value that represents the form performance.

\section{METHODOLOGY}

This study investigates 90 firms listed in Muscat Securities Market for the fiscal year 2019. The data collection was based on reports issued online from the website of Muscat Securities Market (MSM). Our study is quantitative, and the data collection is for the year 2019. The method of data collection is a cross-sectional study. It utilised a Structural Equation Modelling (SEM) with Partial Least Square (PLS) approach to analyse the hypotheses of the current study.

These measurements of the current study for its independent and dependent variables that represented by the determinants of control mechanisms, audit committee and financial performance are shown below:

1. Board Size (B-SZ): measurement of the board size is based on the number of board members. 
2. Board Independence(B-IND): measurement is based on the number of an independent board of directors' members.

3. Board Meeting (B-MT): measurement is based on the number of board meetings.

4. Audit Committee Size (AC-SZ): measurement is based on the number of members of audit committees.

5. Audit Committee Independence (AC-IND): measurement is based on the number of independent audit committee members.

6. Audit Committee Meeting (AC-MT): measurement is based on the number of audit committee meetings.

Measurement of the dependent variables:

1. Return on Assets (ROA): measurement of ROA is based on the net income / total assets.

2. Return on Equity (ROE): measurement of the ROE is based on net income / total equity.

The below equations explain the models:

$$
\begin{aligned}
& R O A=\alpha+\beta_{1} I N O+B_{2} F R O+B_{3} F Z+\varepsilon \\
& R O E=\alpha+\beta_{1} I N O+B_{2} F R O+B_{3} F Z+\varepsilon
\end{aligned}
$$

\section{RESULTS}

The sample was represented by listed firms in the Muscat Stock Market that belongs to financial, service, and industrial sectors.

Table 1: Population and Sample (Sectors and Firms in Muscat Market Securities 2019)

\begin{tabular}{llll}
\hline No & Sector & Firms Numbers & Sample \\
\hline 1 & Financial & 34 & 30 \\
2 & Services & 39 & 30 \\
3 & Industrial & 42 & 30 \\
& Total & 115 & 90 \\
\hline
\end{tabular}

\section{Descriptive Statistics}

Regarding ROA and ROE as dependent variables, the results of this test show that the average of ROA is $12 \%$, and its standard deviation (SD) is 0.064 . In addition, the value of $24 \%$ and $11 \%$ represent Max. and Min., where the result revealed an average of ROE for $30 \%$ with SD of 0.114 . Also, the Min. And Max. value shows that ROE is $35 \%$ and $27 \%$. While the values for the depended variables were as shown:

The average was equal to $5.17 \%$, and the SD was 1.700 ; Board size was $7.20 \%$, and SD was 1.48 ; The average of the Board meeting was $6.068 \%$, and its SD was 1.568 . Audit size was $3.32 \%$, and SD was 0.559 ; Independence of Audit was $54 \%$, and SD was 0.16; Independence of Board was 0.68\%, and SD was 0.145.

Table 2: Descriptive Statistics of variables

\begin{tabular}{lcccc}
\hline \multicolumn{1}{c}{ Variables } & Mean & Min & Max & Standard-D \\
\hline ROA & 0.012 & -0.241 & 0.118 & 0.064 \\
ROE & 0.033 & -0.352 & 0.275 & 0.114 \\
B-SZ & 7.220 & 5.000 & 10.000 & 1.486 \\
B-IND & 0.683 & 0.253 & 1.000 & 0.145 \\
B-MT & 6.068 & 4.000 & 11.000 & 1.568 \\
AC-SZ & 3.321 & 3.000 & 5.000 & 0.559 \\
AC-IND & 0.548 & 0.282 & 1.000 & 0.168 \\
AC-MT & 5.077 & 2.000 & 11.000 & 1.704 \\
\hline
\end{tabular}

\section{Discriminant Validity}

In PLS for testing the discriminant validity, there are standards applied. The square-root of every AVE for every construct must have a high correlation level, including the other constructs. Thus, to deal with discriminant validity, the square root of each construct in its AVE has to be compared versus the constructs' correlations for all other constructs. 
Table 3: Discriminant Validity Constructs

\begin{tabular}{|c|c|c|c|c|c|c|c|c|}
\hline & ROA & ROE & B-SZ & B-IND & B-MT & AC-SZ & AC-IND & AC-MT \\
\hline $\mathrm{ROA}$ & 1.000 & & & & & & & \\
\hline ROE & 0.833 & 1.000 & & & & & & \\
\hline B-SZ & 0.085 & 0.078 & 1.000 & & & & & \\
\hline B-IND & 0.103 & 0.174 & 0.027 & 1.000 & & & & \\
\hline B-MT & -0.183 & -0.156 & 0.281 & -0.078 & 1.000 & & & \\
\hline AC-SZ & 0.071 & 0.097 & 0.269 & -0.245 & 0.483 & 1.000 & & \\
\hline AC-IND & -0.062 & -0.098 & -0.194 & 0.476 & -0.065 & -0.139 & 1.000 & \\
\hline AC-MT & -0.216 & -0.147 & 0.224 & -0.081 & 0.562 & 0.336 & 0.098 & 1.000 \\
\hline
\end{tabular}

\section{DISCUSSION AND CONCLUSION}

In SMS in Oman context, this study tested the effect of control mechanisms (CM), and audit committee (AC) features on financial performance. Thus, the objective of our study is to investigate the independent variables represented by $\mathrm{CM}$ and $\mathrm{AC}$ on the dependent variable; financial performance represented by ROA and ROE in Omani firms. The independent variable of this study is CM that represented by the size of the board of director, a meeting of the board and its independence. Also, the audit committee (AC), which is represented by its size, meeting and independence.

The results indicate a significant and positive relationship between the independence of the board and financial performance which shows a value of $\mathrm{p}<0.05$ and $\mathrm{t}=1.755$. This finding is in line with a study done by Naciti (2019). This shows the essential role of this independent variable in enhancing financial performance, also, for another independent variable which is audit size which is considered as an essential tool of audit quality. The measurement of the variable is via computing several persons that service in this committee audit in the firm as explained by Nuryanah, \& Islam, (2011). In addition, the results revealed a significant and positive relationship between the size of audit committee size and financial performance as the values are $\mathrm{P}<0.05$ and $\mathrm{t}=1.634$ with the performance indicator which is $\mathrm{ROE}$ with a value of $\mathrm{P}<0.05$ and $\mathrm{t}=1.478$. This revealed that when the size of the audit committee is with several numbers of members, this will lead to the high performance of the firms in Oman, which is good indicators. This result is in line with a previous study of Ahmed et al. (2020), and also with another study done by Pillai and Al-malkawi (2017).

The main aim of the current study is to investigate the link between control mechanisms and audit features to enhance the achievements of the firms in Oman for the year 2019. This study utilised meeting of the board, size of the board, independence of the board, audit committee size as independent variables for the control mechanisms and their impact on firm financial performance that represented by ROA and ROE. The results reveal that the size of the audit committee in the firms listed in MSM in Oman is positively related to both ROA and ROE. Also, the findings show that there is a positive and significant relationship between the independence of the board and ROE. Moreover, the results show a significant and positive between the meeting of the board committee and ROE. We realised from our results thy the majority of the hypotheses are not supported. In that, size of the board and both ROE and ROA, in addition, the independence and meeting of the committee are not supported in their link with ROA. Our study found that there is a positive link between these two independent variables and form performance; therefore, our result is in line with the notion of agency theory. Our work introduces an understanding of the control mechanisms' elements beside audit comma features and their effect on financial performance in the firms listed in the Oman market. There is a defence in the results among the firms, where some of them the relations were positive and others negative. So, this establishes for a recommendation that there should be a moderator variable must be tested between the IVs and DVs of the present study by the future researchers.

\section{RECOMMENDATION}

The current work investigated the links among control mechanisms and audit features, and firm financial performance. The literature review in this area has faced a scarcity in investigating this link, and their impact on financial performance as the current study fills this gap via testing its variables: board diversity $\mathrm{m}$, culture and review quality that all would firmly have a significant impact on firm financial performance. In addition, our study suggested to test the same variables but instead searching for other suitable theories such as stakeholder, supervision, and also others. Nevertheless, the findings and recommendations of the current work must be explained in light of limitations that lead to creating a fruitful area for future studies. Firstly, the year that we collected the data from the firms is 2019, which means the current study applied across a sectional study in collect and analysing data of Omani firms. Secondly, we also strongly recommend the researchers to test the same variables that we used but in doing a comparative study between Oman and another country in the GCC. Thirdly, the model developed in the current study can be further extended via including another sector, such as the financial sector.

\section{LIMITATIONS OF THE STUDY}

The model of the current study is not comprehensive. It involves a limited number of control mechanisms to make the empirical test of a variety of control mechanisms factors among the model factors feasible. In addition, we applied the set of mechanisms on just non-financial sector while there is another sector that could also apply such mechanisms in 
it. Moreover, the study is cross-sectional analysis while there is a panel analysis as well that could be done for a few numbers of years in the same sector and another.

\section{ACKNOWLEDGEMENT}

I want to thank my students (Majdah Saif Al-Siyabi and Hajar Hamed Al-Amri) Accounting Department in CEMIS, University of Nizwa, that they were under my supervision in the graduation project for their efforts in collecting data to be used in this research.

\section{REFERENCES}

Abdallah, A. A. N., \& Ismail, A. K. (2017). Corporate governance practices, ownership structure, and corporate performance in the GCC countries. Journal of International Financial Markets, Institutions and Money, 46, 98-115.

Aguilera, R. V., \& Haxhi, I. (2019). Comparative corporate governance in emerging markets. The Oxford handbook of management in emerging markets, 185-210.

Ahmed, E. R., Alabdullah, T. T. Y., Thottoli, M. M., \& Maryanti, E. (2020). Does Corporate Governance Predict Firm Profitability? An Empirical Study in Oman. The International Journal of Accounting and Business Society, 28(1), 127-143.

Akira, F. (2020). The Effects of M\&A on Corporate Performance in Japan: DID analysis in the Era of Corporate Governance Reform. Japan and the World Economy, 101013.

Alabdullah, T. T. Y., Laadjal, A., Ahmed, E. R., \& Al-Asadi, Y. A. A. (2018). Board features and capital structure in emerging markets_-Journal of Advanced Management Science Vol, 6(2).

Alabdullah, T. T. Y., Ahmed, E. R., \& Muneerali, M. (2019). Effect of Board Size and Duality on Corporate Social Responsibility: What Has Improved in Corporate Governance in Asia?. Journal of Accounting Science, 3(2), 121-135.

Alabdullah, T. T. Y., Ahmed, E. R., \& Nor, M. I. (2019). Do board characteristics provide more enhancement for firm financial performance? A corporate governance perspective.New Challenges in Corporate Governance: Theory and Practice, 89- 91.

Alabdullah, T. T. Y., Nor, M. I., \& E. Ries (2018). The Determination of Firm Performance in Emerging Nations: Do Board Size and Firm Size Matter. Management 5, 57-66.

Al-ahdal, W. M., Alsamhi, M. H., Tabash, M. I., \& Farhan, N. H. (2020). The impact of corporate governance on the financial performance of Indian and GCC listed firms: An empirical investigation. Research in International Business and Finance, 51, 101083.

Forcadell, F. J., Sanchez-Riofrio, A., Guerras-Martín, L. Á., \& Romero-Jordán, D. (2020). Is the restructuring-performance relationship moderated by the economic cycle and the institutional environment for corporate governance?. Journal of Business Research, 110, 397-407.

Gao, W., Huang, Z., \& Yang, P. (2019). Political connections, corporate governance and M\&A performance: Evidence from Chinese family firms. Research in International Business and Finance, 50, 38-53.

García-Sánchez, I. M., Hussain, N., \& Martínez-Ferrero, J. (2019). An empirical analysis of the complementarities and substitutions between effects of CEO ability and corporate governance on socially responsible performance. Journal of Cleaner Production, 215, 1288-1300.

Gibson, M. S. (2003). Is corporate governance ineffective in emerging markets? Journal of Financial and Quantitative Analysis, $38(1), 231-250$.

Hereher, M. E. (2020). Assessment of Infrastructure Vulnerability to Tsunamis upon the Coastal Zone of Oman Using GIS. Geosciences, 10(5), 175.

Kushkowski, J. D., Shrader, C. B., Anderson, M. H., \& White, R. E. (2020). Information flows and topic modelling in corporate governance-Journal of Documentation.

Lo, S. F., \& Sheu, H. J. (2007). Is corporate sustainability a value-increasing strategy for business?. Corporate Governance: An International Review, 15(2), 345-358

Naciti, V. (2019). Corporate governance and board of directors: The effect of board composition on firm sustainability performance. Journal of Cleaner Production, 237, 117727.

Nagirikandalage, P. (2020). Accounting and Sustainable Development: A Case of Poverty Reduction in an Emerging Economy. Zero Hunger, 1-7.

Pillai, R., \& Al-Malkawi, H. A. N. (2018). On the relationship between corporate governance and firm performance: Evidence from GCC countries. Research in International Business and Finance, 44, 394-410.

Rashid, A. (2018). Board independence and firm performance: Evidence from Bangladesh. Future Business Journal, 4(1), 34-49.

Thomsen, S., Pedersen, T., \& Kvist, H. K. (2006). Blockholder ownership: Effects on firm value in market and control based governance systems. Journal of Corporate finance, 12(2), 246-269. 


\section{AUTHORS' BIOGRAPHY}

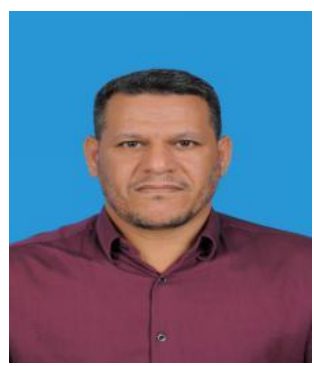

Essia Ries Ahmed is currently working as an assistant of Professor at the University of Nizwa. He received his PhD from University Malaysia Perlis (UniMap), master's degree in Accounting from Universiti Sains Malaysia (USM). He has published articles in several Scopus Journals, and proceedings and presented papers at both national and international conferences. Dr Essia Ries Ahmed is the reviewer and member of the editorial board in several journals.

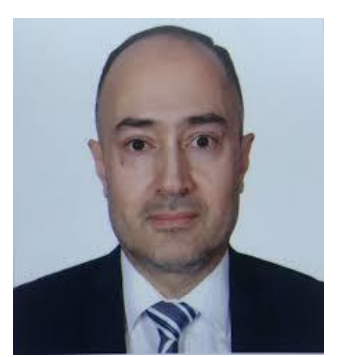

Associate Professor Tariq Tawfeeq Yousif Alabdullah holds a PhD in accounting from Universiti Sains Malaysia (USM). He is currently a lecturer in accounting in the University of Basrah, Iraq. His research interests are mainly in the areas of Accounting and corporate governance. He has published several papers and presented 27 papers in various international conferences in the USA and Europe. He is an editorial board member in the editorial board for more than 57 International conferences and international Journals.

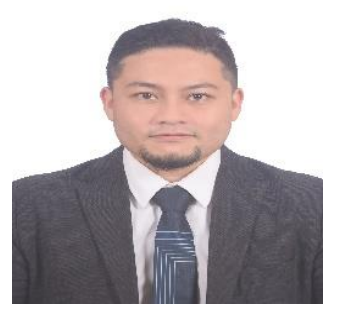

Muhammad Shabir Shaharudin received his PhD from Universiti Malaysia Pahang and MBA in International Business from Universiti Sains Malaysia while his bachelor's degree in international business was from Limkokwing University Malaysia. His area of interest includes environmental supply chain management, supply chain management, ecoinnovation, international business, and business engineering.

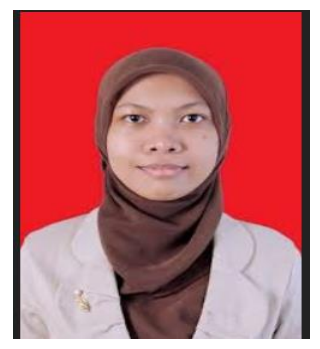

Eskasari Putri is lecturer in Accounting at the Muhammadiyah University of Surakarta, Indonesia. She is the Editorial in Chief of Abdi Psikonomi Journal and Riset Akuntansi dan Keuangan Indonesia Journal. 